\title{
A POPULATION-BASED STUDY: THE APPROPRIATENESS OF DRUG USE IN THE ELDERLY ACCORDING TO BEERS CRITERIA
}

Turkish Journal of Geriatrics DOI:10.31086tjgeri.2018137962 2018;21 (1):1-15

- Birol ÇIBIK ${ }^{1}$

- Erkan Melih ŞAHIN²

- Mehmet Göktuğ KILINÇARSLAN²
CORRESPONDANCE

Mehmet Göktuğ KILINÇARSLAN Çanakkale Onsekiz Mart University Faculty of Medicine, Department of Family Medicine Çanakkale, Turkey

Phone: 2862636471 e-mail: goktugmk@gmail.com

Received: 15/11/2017 Accepted: 09/02/2018

Tokat State Hospital, Family Medicine Clinic Tokat, Turkey

${ }^{2}$ Çanakkale Onsekiz Mart University Faculty of Medicine, Department of Family Medicine Çanakkale, Turkey

\section{Abstract}

Introduction: The elderly population has the highest rates of drug use and is more sensitive to drug effects. Inappropriate drug use can cause unwanted effects in such a population. We aimed to evaluate inappropriate drug use in the elderly population according to Beers criteria.

Materials and Method: This cross-sectional, descriptive study used a simple systematic method to select individuals aged $>65$ years residing in Kepez district of Canakkale. All medicines used by participants were identified and evaluated according to Beers criteria.

Results: The mean age of the participants was $74.1 \pm 6.5$ (65-91) years. In our study, $95.7 \%$ of the participants had at least one chronic illness and $84.5 \%$ had at least three chronic illnesses. The mean total number of drugs used was 5.0 $\pm 3.2(0-15)$. According to Beers criteria, inappropriate drug use was detected in 35 (30\%) instances. Non-steroidal anti-inflammatory drugs were the most frequent inappropriately used drugs in the study population $[n=13$ $(11.2 \%)]$.

Conclusion: In this study, the rates of inappropriate drug use $(35 ; 30 \%)$ were lower than those previously reported. Our findings underline the importance of adhering to guidelines for rational drug use in prescribing medications to elderly.

Keywords: Potentially inappropriate medication list; Drug interactions; Drug-related side effects and adverse reactions; Chronic disease; Inappropriate prescribing; Turkey

\section{ARASTTIRMA}

\section{TOPLUM TABANLI BİR ÇALIŞMA: YAŞLILARDA ILAÇ KULLANIMININ BEERS KRITERLERINE UYGUNLUK DURUMU}

\section{$\ddot{O}_{z}$}

Giriş: Yaşlı popülasyon en yüksek ilaç kullanım oranına sahip olup ilaç etkilerine daha duyarlıdırlar. Uygunsuz ilaç kullanımı bu hastalarda istenmeyen etkilerin ortaya çıkmasına neden olabilmektedir. Bu çalışmada Beers kriterlerine göre yaşıllarda uygunsuz ilaç kullanımının değerlendirilmesi amaçlanmaktadır.

Gereç Yöntem: Kesitsel, tanımlayıcı desendeki araştırmamızda Çanakkale Kepez beldesinde ikamet eden 65 yaş ve üzeri bireylerden basit sistematik yöntemle örneklem seçildi. Çalışmaya alınan yaşılların aktif kullandıkları tüm ilaçlar belirlenip Beers kriterleri açısından değerlendirildi.

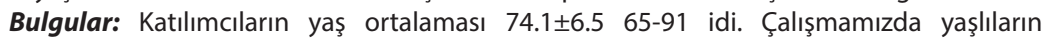
\%95.7'sinde en az bir kronik hastalık, \%84.5'inde ise en az üç kronik hastalık varlığı saptanmıştır.

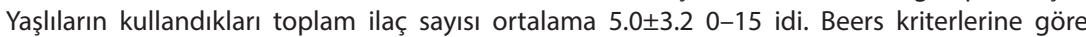
toplam 35 (\%30) durumda uygunsuz ilaç kullanımı saptandı. Çalışmamızda en sık uygunsuz kullanılan ilaç olarak 13 (\%11.2) bireyde non-steroidal antienflamatuar ilaçlar saptandı.

Sonuç: Literatürdeki diğer araştırmalara göre daha az oranda olsa da çalışmamızda yaşlı hastalarda $(35 ; \% 30)$ uygunsuz ilaç kullanımı olduğu saptanmıştır. Yaşlı hastalara ilaç reçete edilirken akılcı ilaç kullanım kurallarına uymanın önemi ortaya çıkmıştır.

Anahtar sözcükler: Potansiyel uygun olmayan ilaç listesi; İlaç etkileşimi; illaç yan etkisi; Kronik hastalık; Uygunsuz reçeteleme; Türkiye 


\section{INTRODUCTION}

Elderly individuals are more prone to experience drug adverse effects and drug-drug interaction because of physiological changes associated with ageing, which are liable to affect drug metabolism (1). The population that consumed the most drugs was aged $\geq 65$ years, and $17 \%-19 \%$ consumed at least 10 drugs per week (2).

The use of drugs in elderly people is often inappropriate partly because of the complexities of prescribing as well as other patient, provider, and health-system factors so inappropriate prescribing in elderly people has therefore become an important public-health issue worldwide. Even while there are too many terms to describe prescribing quality (such as good, poor, optimal), the term of appropriate drug use can be used to express the quality level needed to be reached in practice (3).

Various criteria have been developed to guide appropriate drug use in elderly individuals and they can be grouped in 1. implicit criteria (judgement based) such as the Medication Appropriateness Index-MAI and 2. explicit criteria (criterion-based) such as Beers and STOPP/START criterias (4).

Explicit criteria are composed by literature review and expert consensus. Using explicit criteria is easier than using implicit criteria in practice because of explicit criteria are just focus on drugs and/or drug-disease relation without any need to clinical judgement (such as patient preferences, all medicines of patient) (5).

O'Mahony and Gallagher (6), offer six principles for selecting optimal explicit criteria: (i) organization based on physiological systems and rapid applicability in daily practice; (ii) inclusion of the more common errors of commission and omission in prescribing for older adults; (iii) generalizability to the global community of physicians and pharmacists; (iv) ease of interface with computer records of co-morbidities of patients and lists of drugs; ( $v$ ) ability to reduce the prevalence of potentially inappropriate medications in older adults in different settings; and (vi) ability to reduce the incidence and negative impact of adverse drug reactions but there is no explicit criteria can fulfil all principles (4). Because of there is not any ideal criteria for screening inappropriate drug use, any of them can be selected according to situations such as for research or daily clinical routine (5).

The use of certain medications in elderly individuals should be avoided according to the Beers criteria developed by the American Geriatrics Society to prevent inappropriate drug use among elderly and updated in 2015 (Tables 2-4). In these criteria, all drugs with a high potential to cause adverse effects in elderly individuals are listed; adverse effects of each drug group are specified and recommendations for use are provided. Depending on the changes in kidney function and drug interactions in elderly individuals, special restrictions may be required with respect to dosage, dose interval and treatment duration. Beers criteria were found to be a highly useful guide for reducing inappropriate drug use, minimising drug-related adverse effects and reducing treatment costs (7). Inappropriate drug use rate according to Beers criteria change from \%10.3 to \%66.7 in literature $(8,9)$.

Beers criteria has also some limitations but it is still widely used (10). Also Beers criteria is most cited explicit criteria in literature (4). STOPP/START has three implicit prescribing rules unlike Beers criteria, that means using STOPP/START criteria to screen inappropriate drug use need clinical judgement (11).

In this study we aimed to assess the appropriateness of drug use in the elderly population in the Kepez district of Canakkale on the basis of Beers criteria. 


\section{MATERIALS AND METHOD}

\section{Sampling methodology}

This cross-sectional, descriptive study included 1161 individuals aged $\geq 65$ years residing in Kepez district of Canakkale. The sample size is calculated 124 people for estimated prevalence for inappropriate drug use rate of 0.10 with the precision value of 0,05 (8). A simple systematic method was used to select the study sample. The list of elderly individuals was obtained from the Kepez Municipality and sorted according to age and sex. One from every 10 in a row like 1.-11.-21. were invited to participate in the study. The selected individuals were contacted via telephone calls or by personal visits to their residence addresses. In case the selected individuals were not reachable or did not meet the selection criteria, the next individual in the list was contacted till the set total number of targeted participants was achieved.

\section{Inclusion and exclusion criteria}

Individuals aged $\geq 65$ years were eligible for the study. Exclusion criteria included presence of illness or disability that would prevent compliance with the study method (such as the presence of a psychiatric disorder that would disrupt reality assessment or a medical condition that would impair the ability to respond to questions).

\section{Application}

A total of 37 elderly persons could not be reached because of death, change in address or owing to errors in the recorded data. Two participants with dementia and hearing loss were excluded, whereas 36 (\%31) participants were excluded because they did not agree to participate in the study. Data collection was completed after reaching 10\% (116) of the target group.

Participants were invited to the Family Medicine clinic at the Canakkale Onsekiz
Mart University Hospital for interview and 30 participants were interviewed at their home after they expressed their inability to visit the clinic. Written informed consent of the participants was obtained before administering the questionnaires. The data were anonymously recorded.

\section{Permits and approvals}

Before initiating the study, approval was obtained from the Clinical Research Ethics Committee at the Canakkale Onsekiz Mart University. Elderly individuals invited to participate in the study were provided verbal data regarding the study, and written consent was obtained.

\section{Statistical analysis}

Data were analysed using the descriptive features in IBM SPSS v20 software. Nonparametric analysis (Mann Whitney $U$ test for two independent samples, Kendall's tau-b correlation) were used when appropriate.

\section{RESULTS}

\section{Sociodemographic characteristics}

Of the 116 elderly individuals, 56 (48.3\%) were males and 60 (51.7\%) were females. The mean age of the participants was $74.1 \pm 6.5$ (65-91) years; there was no significant difference between the mean age of males (73.7 \pm 6.2 years) and those of females ( $74.4 \pm 6.8$ years) $(p=0,680)$. Furthermore, 77 (66.4\%) participants were married and 39 (33.6\%) were widowed. Seventy-five (64.7\%) participants were primary school graduates. For male participants, the mean weight was $78.5 \pm 14.6$ (range, 50-135) kg, mean height was $171.2 \pm 7.1(155-195) \mathrm{cm}$ and mean body mass index (BMI) was $26.7 \pm 5.6 \mathrm{~kg} / \mathrm{m}^{2}$. For of female participants, the mean weight was $70.9 \pm 13.0$ (44-110) kg, mean height was $155.7 \pm 7.0$ (143171) $\mathrm{cm}$ and mean BMI was $29.3 \pm 5.6 \mathrm{~kg} / \mathrm{m} 2$. 


\section{Chronic diseases}

In our study, $95.7 \%$ of the participants had at least one chronic illness and $84.5 \%$ had at least three chronic illnesses. Five (4.3\%) participants stated that they did not have any chronic disease. The mean number of chronic diseases in the study population was $5.7 \pm 2.9(0-12)$. The chronic diseases and their prevalence in our study population are given in Table 1.

\section{Drug use, adverse effects and drug-drug interactions}

Eleven (9.5\%) participants were not using any medication. The mean total number of drugs used by the participants was $5.0 \pm 3.2(0-15)$; the average daily dose of medication was $5.7 \pm 4.1$ (0-26). In our study, the most frequently used medicines according to the anatomic therapeutic chemical classification were cardiovascular system drugs (69.8\%), digestive system and metabolism drugs (62.1\%), nervous system drugs (47.4\%), blood and blood-forming drugs (44.8\%), musculoskeletal drugs (37.1\%), sensory organ drugs (13.8\%) and respiratory system drugs (12.1\%).

Sixty-four (55.2\%) participants used five or more drugs per day. A positive correlation was observed between the number of medications used and age (tau-b=0.140; $p=0.036$ ). The total number of drugs used by female participants $(5.6 \pm 2.9)$ was significantly higher than that used by male participants $(4.3 \pm 3.4)(U=1208.0$; $p=0.009)$. There was no significant difference between female $(6.0 \pm 3.4)$ and male $(5.4 \pm 4.8)$ participants $(U=1441.0 ; p=0.185)$ with respect to the number of daily medication doses. The incidence of chronic illness among the participants was positively correlated with the number of medications used (tau- $b=0.546$; $p<0.001)$ and daily doses of medication (tau-b=0.470; $p<0.001$ ).

There was a positive correlation between the number of drugs used by the participants and the incidence of adverse effects (tau- $b=0.288$; $p<0.001)$. The number of medicines used and the number of medicines taken daily were significantly higher in participants with adverse effects (7.0 \pm 3.1 and $8.2 \pm 3.5$, respectively) than in those who did not have experience any adverse effects $(4.4 \pm 3.0$ and $4.9 \pm 4.0$, respectively) $(U=651.0 ; \quad p<0.001$ and $U=580.0 ; \quad p<0.001$, respectively).

According to Beers criteria updated in 2015 by the American Geriatrics Society, Twentyfour (20.7\%) participants were on long-term NSAID therapy. Eleven (9.5\%) participants who use NSAIDs were using PPI, whereas 13 (11.2\%) participants were inappropriately using NSAIDs. Forty-five (38.8\%) participants were using proton-pump inhibitors (PPIs). Except for high-risk individuals such as those on long-term non-steroidal anti-inflammatory drug (NSAID) therapy, the use of PPI for more than 8 weeks is inappropriate in elderly individuals. We were unable to assess the appropriateness of use of PPIs owing to inadequate data regarding the duration of use of PPI (Table 2).

Inappropriate drug use that could cause aggravation of disease in elderly individuals owing to drug-disease interactions was also evaluated according to Beers criteria. Inappropriate NSAID use was detected in two (1.7\%) of eight participants with chronic heart failure. In two (1.7\%) of eight participants with dementia, inappropriate drug use, which could lead to disease aggravation, was detected. Participants with syncope, delirium and history of falls could not be evaluated because of inadequate data (Table 3).

Drug groups that are not suitable for use in combination in elderly individuals owing to drugdrug interactions were evaluated according to Beers criteria. In three (2.6\%) participants, combined use of three CNS-active drugs 
was detected, and in one (0.9\%) participant, combined use of five CNS-active drugs was found (Table 4). Overall, we determined 35 (30\%) instances of inappropriate drug use according to
Beers criteria. The numbers and percentages of participants who met the 2015 Beers criteria are given in Tables 2-4.

Table 1. Prevalence of chronic diseases in the study population.

\begin{tabular}{|c|c|c|}
\hline Diseases & $\mathbf{n}$ & $\%$ \\
\hline None & 5 & 4.3 \\
\hline Hypertension & 76 & 65.5 \\
\hline $\begin{array}{l}\text { Diseases of the sensory organs (cataract, glaucoma, visual defects, xeroph- } \\
\text { thalmia, hearing loss, etc.) }\end{array}$ & 69 & 59.5 \\
\hline $\begin{array}{l}\text { Diseases of the gastrointestinal system (peptic ulcer, gastritis, reflux, consti- } \\
\text { pation, irritable bowel disease, etc.) }\end{array}$ & 65 & 56.0 \\
\hline Gonarthrosis & 57 & 49.1 \\
\hline $\begin{array}{l}\text { Cardiovascular diseases (coronary artery disease, arrhythmia, valve diseases, } \\
\text { orthostatic hypotension, peripheral vascular diseases, etc.) }\end{array}$ & 55 & 47.4 \\
\hline Hyperlipidaemia & 49 & 42.2 \\
\hline Osteoporosis & 40 & 34.5 \\
\hline Rheumatic diseases (joint rheumatism/aching joints, gout, etc.) & 38 & 32.8 \\
\hline Diabetes mellitus & 36 & 31.0 \\
\hline $\begin{array}{l}\text { Neurological/cerebrovascular diseases (Alzheimer's disease, Parkinson's dis- } \\
\text { ease, ischaemic or haemorrhagic stroke, migraine, etc.) }\end{array}$ & 36 & 31.0 \\
\hline Anaemia (Iron deficiency anaemia, chronic disease anaemia, etc.) & 35 & 30.2 \\
\hline Benign prostatic hyperplasia & 24 & 20.7 \\
\hline $\begin{array}{l}\text { Psychological diseases (depression, anxiety, sleep disturbance, psychotic dis- } \\
\text { orders, etc.) }\end{array}$ & 21 & 18.1 \\
\hline Lung diseases (chronic obstructive pulmonary disease, asthma, etc.) & 19 & 16.4 \\
\hline Cancer (lung, colon, stomach, breast, prostate, lymphoma, leukaemia) & 13 & 11.2 \\
\hline Thyroid/parathyroid diseases & 9 & 7.8 \\
\hline $\begin{array}{l}\text { Urinary system diseases (urinary incontinence, urinary infection, chronic kid- } \\
\text { ney disease, etc.) }\end{array}$ & 9 & 7.8 \\
\hline Skin diseases/allergic disorders & 6 & 5.2 \\
\hline
\end{tabular}




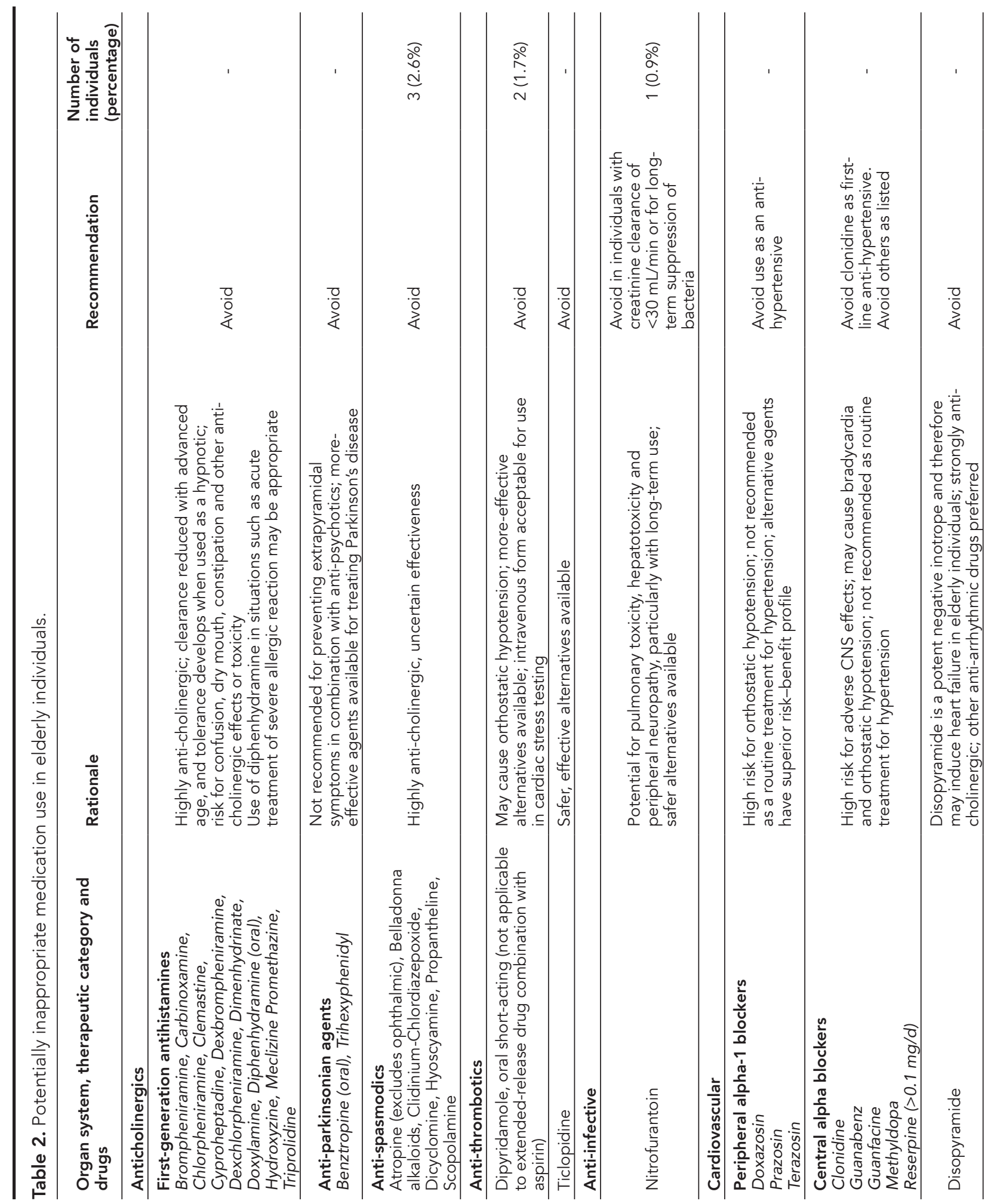




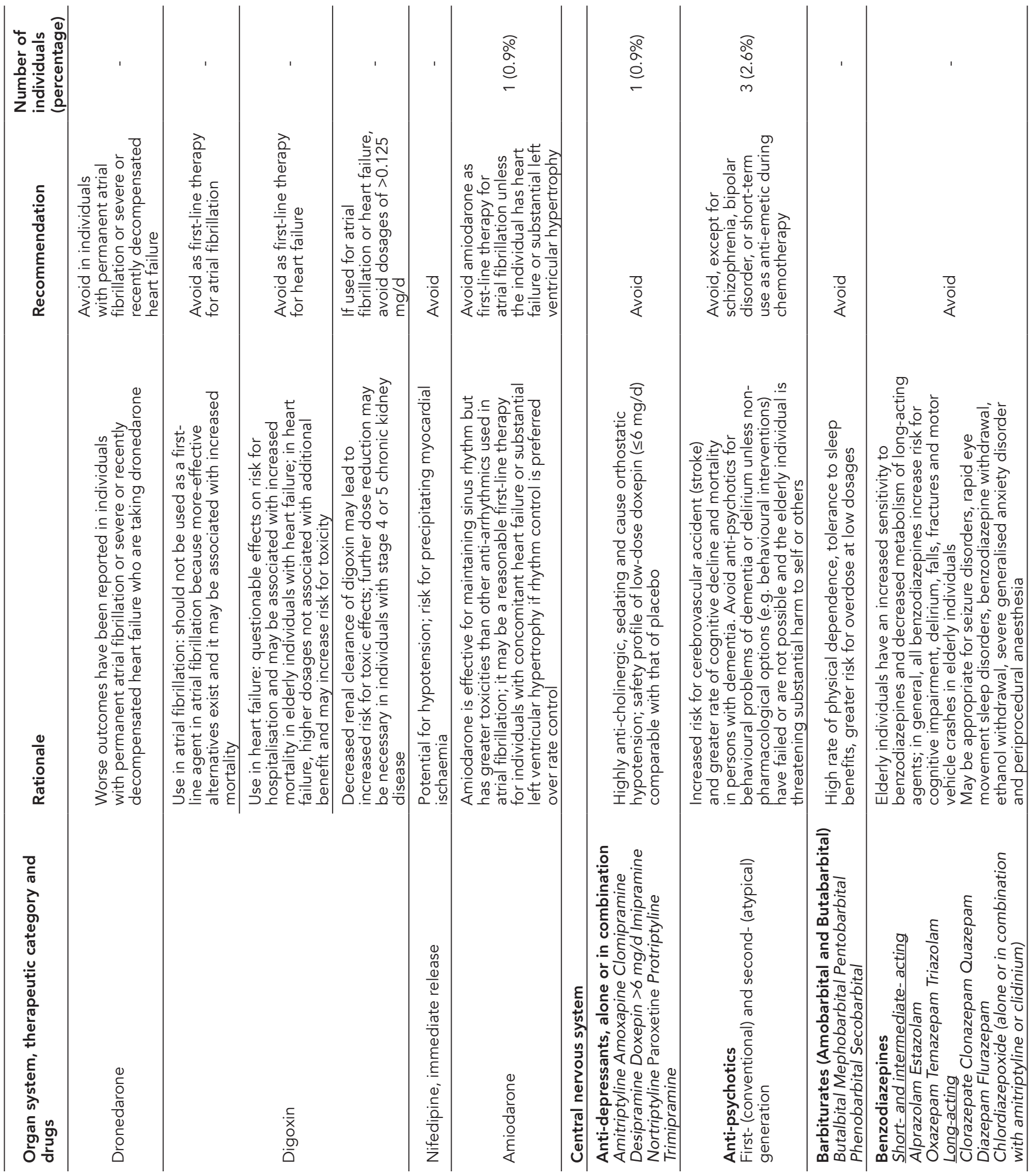




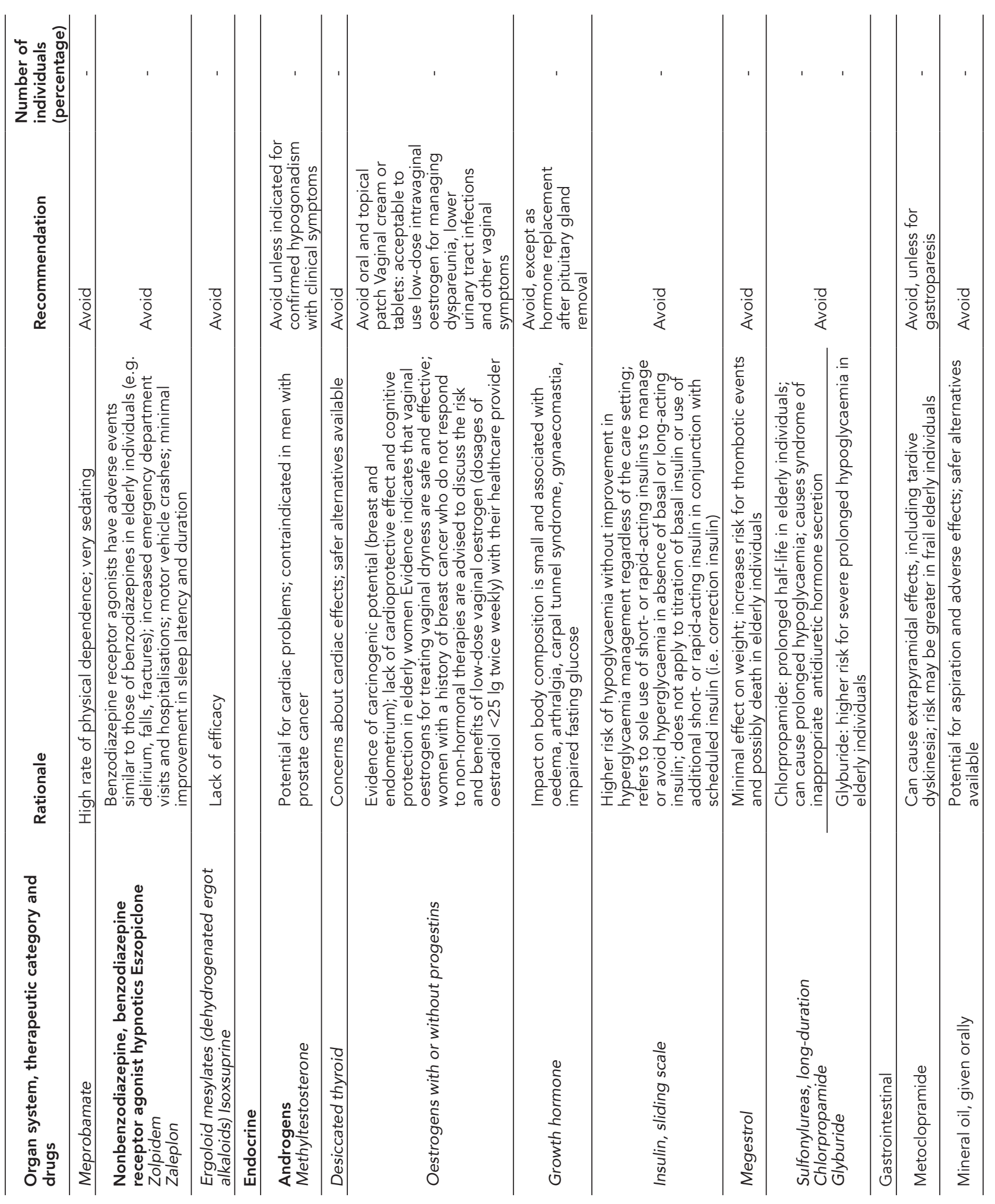




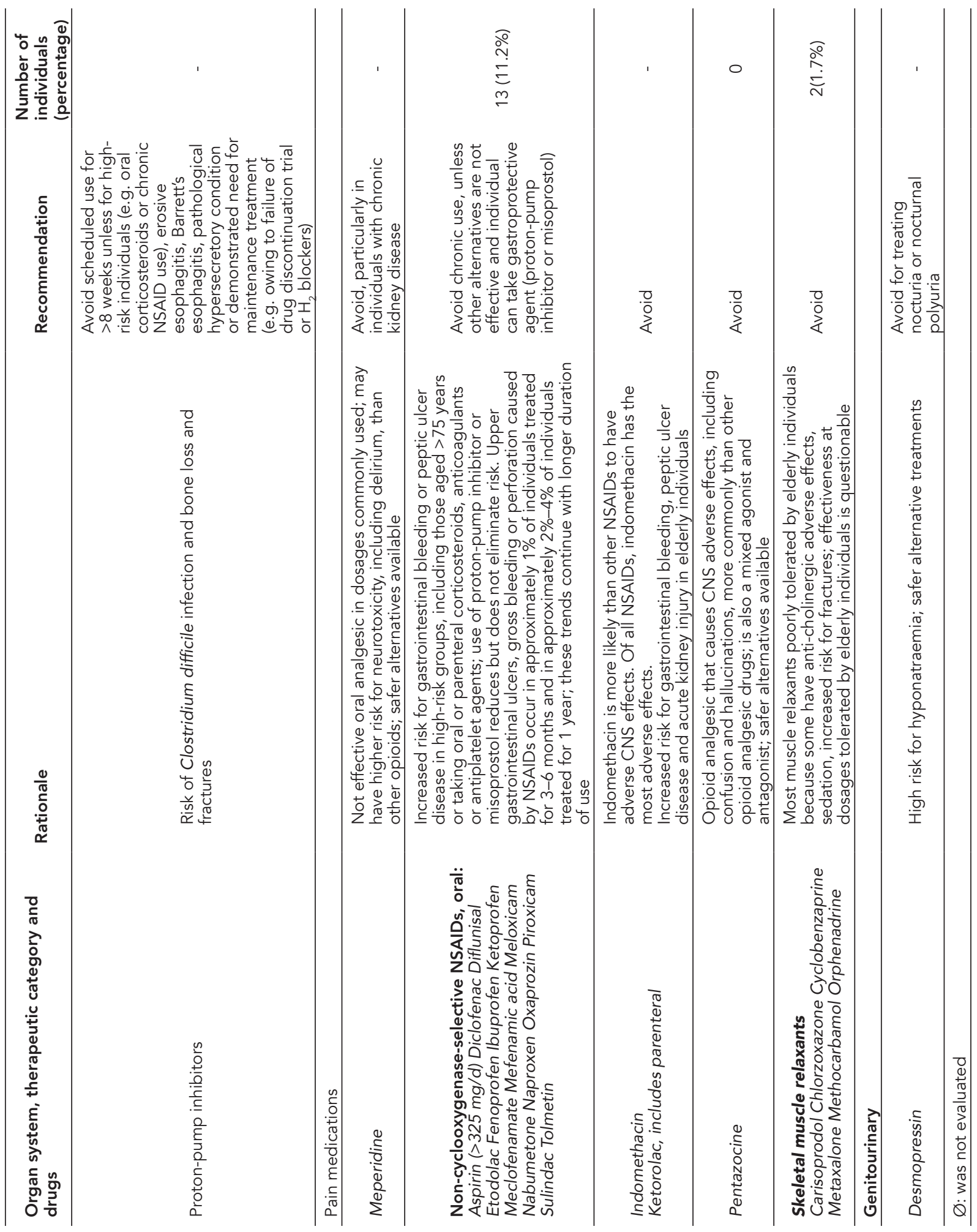




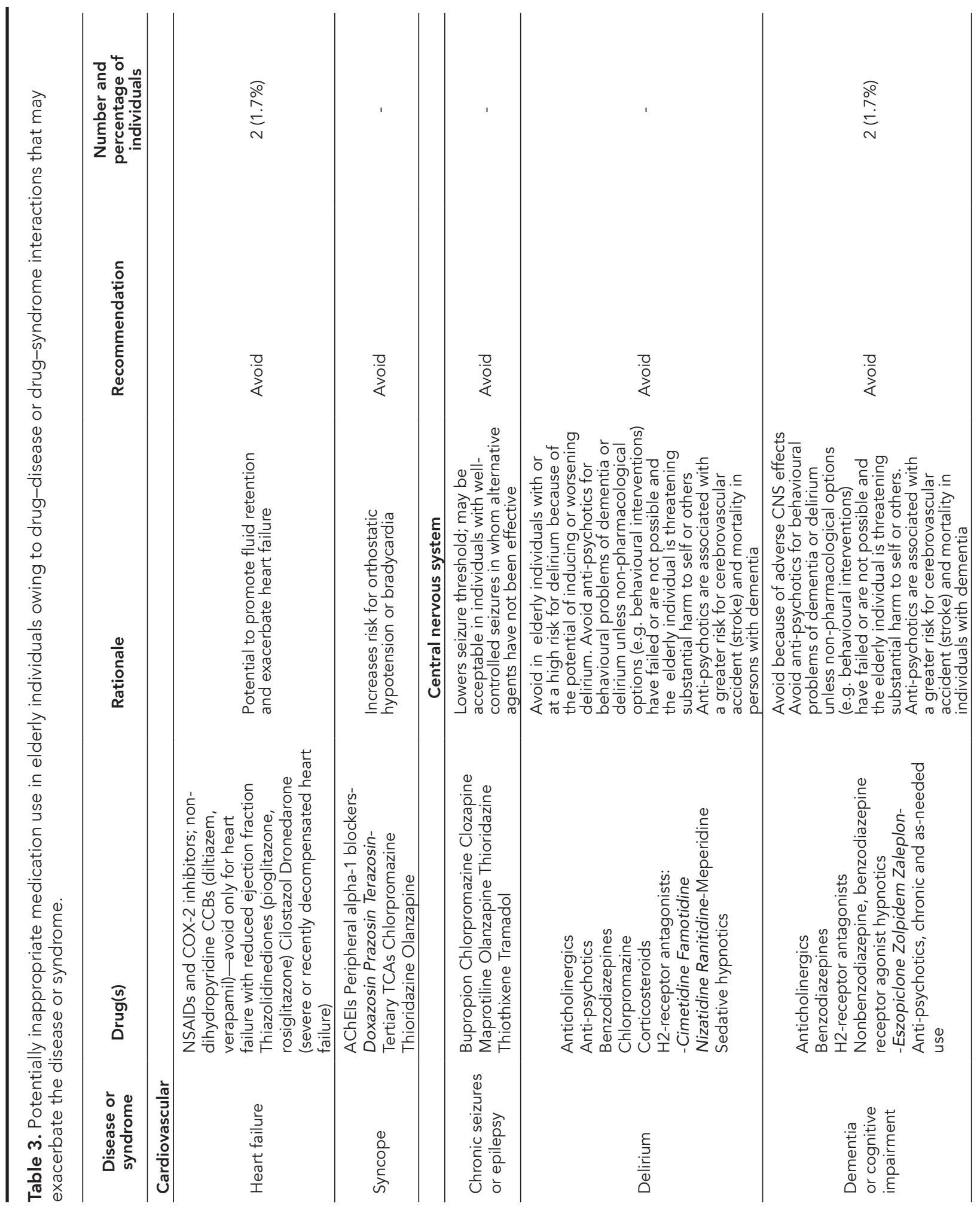




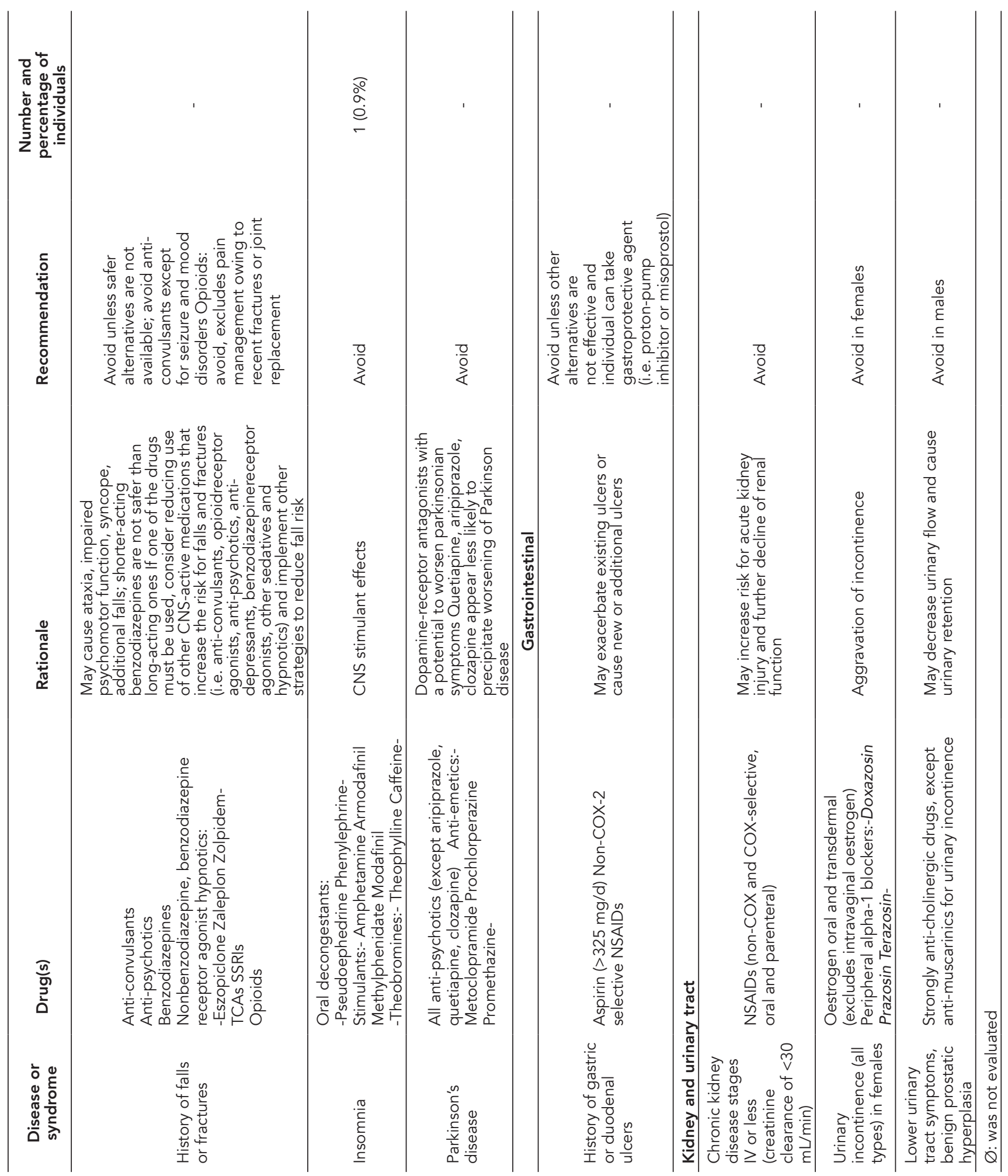




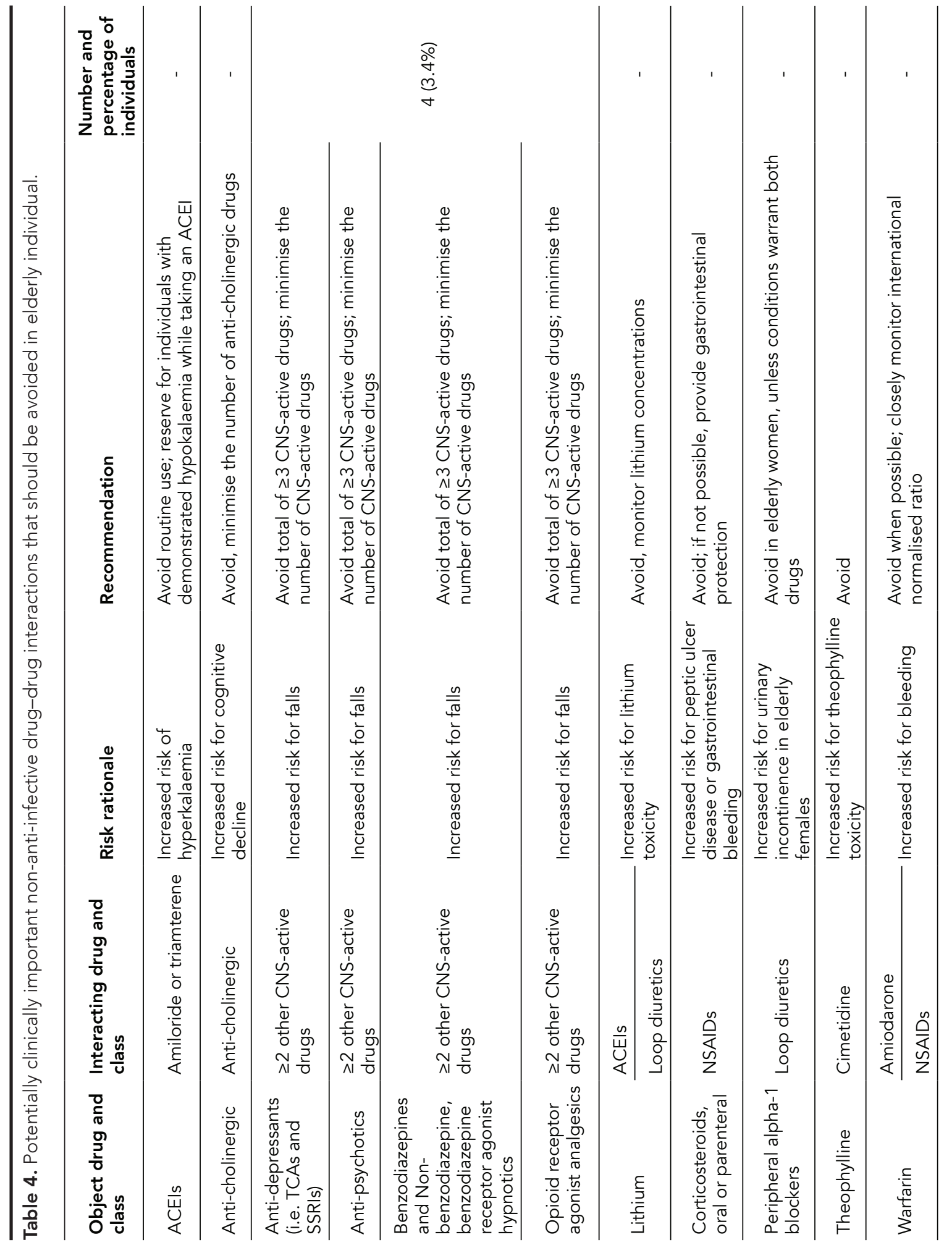




\section{DISCUSSION}

Ageing is associated with an increase in the incidence of many diseases, particularly chronic diseases (12). In a study conducted in the United States, 86\%-92\% of individuals aged $\geq 65$ years were found to have at least one chronic illness; whereas $30.7 \%-41.3 \%$ of individuals had at least three concomitant chronic illnesses (13). In our study, $95.7 \%$ of participants had at least one chronic disease, whereas $84.5 \%$ of participants had at least three chronic diseases. While the proportion of individuals with one chronic disease was comparable between the two studies, the rate of comorbidity in our study was much higher than that reported in the study conducted in the United States. Greater disease burden naturally leads to an increased drug use. The proportion of elderly individuals in the United States is 13\%, and they account for $34 \%$ of the population that uses written prescriptions. It was found that $95 \%$ of elderly individuals use drugs at least once a week, and $12 \%$ use drugs $\geq 10$ times per week (14). In the present study, $55.2 \%$ of participants used five or more medications per day, while a corresponding rate of $66.9 \%$ was recently reported in India (15).

\section{Potentially inappropriate medication use}

In our study, inappropriate drug use was found in $22.4 \%$ of the participants according to Beers criteria [NSAID (11.2\%), antispasmodic drug (2.6\%), muscle relaxant (1.7\%) and dipiridamol (1.7\%)]. Nitrofurantoin and amiodarone were each used by $0.9 \%$ of participants; these were considered inappropriate drugs for use in the elderly population. The use of PPI could not be assessed owing to lack of data regarding the duration of use.

\section{Potentially drug-disease or drug-syndrome interactions}

In our study, drug use in five (4.3\%) participants were found to be inappropriate according to Beers criteria because of the potential for drug-disease interaction. Inappropriate drug use was detected in two $(1.7 \%)$ of eight participants with chronic heart failure; all were attributable to inappropriate NSAID use. Doctors need to be careful while prescribing a combination of drugs to prevent unwanted situations; for example, non-dihydropyridinederived calcium channel blockers are found in many anti-hypertensive medications and their use is not appropriate in individuals with chronic heart failure. Two (1.7\%) of eight participants with dementia were categorised as those with inappropriate drug use (inappropriate use of anti-psychotic and $\mathrm{H}_{2}$ receptor blocker, respectively). $\mathrm{H}_{2}$ receptor antagonists are generally believed to be safe drugs; however, according to Beers criteria, these should be avoided in individuals with dementia. Although found at a very low rate in our study, in a previous study (15), $\mathrm{H}_{2}$ receptor antagonists were found to be the most prescribed inappropriate drugs according to Beers criteria. In our study, one $(0.9 \%)$ of the four participants with insomnia was categorised as an inappropriate drug user (inappropriate use of psychostimulant drug). Although we did not detect inappropriate use of oral decongestants in our study, doctors should avoid prescribing oral decongestants to individuals with complaints of insomnia because oral decongestants are found in many over-the-counter medications. Although these are included in Beers criteria, studies regarding syncope, delirium and falling history could not be assessed owing to inadequacy of data (Table 3).

\section{Potentially drug-drug interactions}

In our study, four (3.4\%) participants had inappropriate drug use owing to potential drugdrug interactions according to Beers criteria. Three (2.6\%) participants used a combination of three drugs that affected the central nervous system and one $(0.9 \%)$ participant used a combination of five drugs (Table 4).

\section{General considerations}

In our study we found inappropriate drug use in $30 \%$ instances. These data are obtained from population based study and important for Turkey the country that have limited data about inappropriate drug usage. Studies conducted 
overseas have yielded inconsistent results (16). A study in Switzerland found inappropriate drug use in $10.3 \%$ of elderly individuals (8). In another study $66.7 \%$ of elderly individuals used inappropriate drugs (9).

In general, earlier studies in the literature were conducted in individuals who were admitted to emergency services or hospitals with complaints of drug adverse effects. This may explain the lower rates of inappropriate drug use found in our study $(35 ; 30 \%)$. Nevertheless, a communitybased study in Spain found a higher prevalence (44.8\%) of inappropriate drug use than that found in our study (17). Differences can be due to limitation of Beers criteria that it is not applicable outside the US (18).

\section{REFERENCES}

1. Brahma DK, Wahlang JB, Marak MD, Ch Sangma M. Adverse drug reactions in the elderly. J Pharmacol Pharmacother 2013;4(2):91-94. (PMID:23761706).

2. Patterns of medication use in the United States. A Report from the Slone Survey, Boston University. Slone Epidemiology Center, 2006, p 1. [Internet] Available from: http://www.bu.edu/slone/files/2012/11/Slone SurveyReport2006.pdf. Accessed:01.03.2016.

3. Spinewine $A$, Schmader $K E$, Barber $N$, et al. Appropriate prescribing in elderly people: how well can it be measured and optimised? Lancet 2007;370(9582):173-84. (PMID:17630041).

4. Chang C-B, Chan D-C. Comparison of published explicit criteria for potentially inappropriate medications in older adults. Drugs Aging 2010;27(12):947-57. (PMID:21087065).

5. Kaufmann CP, Tremp R, Hersberger KE, Lampert ML. Inappropriate prescribing: a systematic overview of published assessment tools. Eur J Clin Pharmacol 2014;70(1):1-11. (PMID:24019054).

6. O'Mahony D, Gallagher PF. Inappropriate prescribing in the older population: need for new criteria. Age Ageing 2008;37(2):138-41. (PMID:18349010).

7. American Geriatrics Society 2015 Updated Beers Criteria for potentially inappropriate medication use in older adults. J Am Geriatr Soc 2015;63(11):222746. (PMID:26446832).
According to our study results, the rate of inappropriate drug use among elderly individuals is at an unacceptable level. Therefore, adapting to the guidelines of rational drug use in elderly individuals for clinical practice is more important. NSAIDs were found to account for a large proportion of inappropriate drug use in our study. NSAIDs tend to be perceived as non-harmful by the population and are widely used as over-the-counter drugs (19). In addition to adapting to guidelines of rational drug use while prescribing drugs, population-based education interventions should be performed to reduce inappropriate drug use. The physician should follow the guidelines for rational drug use while prescribing drugs and should review the medicines used by elderly individuals during each follow-up visit.

8. Blozik E, Rapold R, von Overbeck J, Reich O. Polypharmacy and potentially inappropriate medication in the adult, community-dwelling population in Switzerland. Drugs Aging 2013;30(7):561-68. (PMID:23553511).

9. Yang P-J, Lee $Y-T$, Tzeng $S-L$, et al. Potentially inappropriate prescribing in disabled older patients with chronic diseases: a screening tool of older persons' potentially inappropriate prescriptions versus Beers 2012 Criteria. Med Princ Pract 2015;24(6):565-70. (PMID:26279164).

10. Bjerre LM, Halil R, Catley $C$, et al. Potentially inappropriate prescribing (PIP) in long-term care (LTC) patients: validation of the 2014 STOPPSTART and 2012 Beers criteria in a LTC population-a protocol for a cross-sectional comparison of clinical and health administrative data. BMJ Open 2015;5(10):e009715. (PMID:26453592).

11. O'Mahony D, O'Sullivan D, Byrne S, O'Connor MN, Ryan C, Gallagher P. STOPP/START criteria for potentially inappropriate prescribing in older people: version 2. Age Ageing 2015;44(2):213-18. (PMID:25324330).

12. Henschel F, Redaelli M, Siegel M, Stock S. Correlation of incident potentially inappropriate medication prescriptions and hospitalization: an analysis based on the PRISCUS List. Drugs-real world outcomes. 2015;2(3):249-59. (PMID:27747571). 
13. Hung WW, Ross JS, Boockvar KS, Siu AL. Recent trends in chronic disease, impairment and disability among older adults in the United States. BMC Geriatr 2011:11:47. (PMID:21851629).

14. Kaufman DW, Kelly JP, Rosenberg L, Anderson TE, Mitchell AA. Recent patterns of medication use in the ambulatory adult population of the United States:the Slone survey. JAMA 2002;287(3):337-44. (PMID:11790213).

15. Narvekar RS, Bhandare NN, Gouveia JJ, Bhandare PN. Utilization pattern of potentially inappropriate medications in geriatric patients in a tertiary care hospital: a retrospective observational study. J Clin Diagn Res 2017;11(4):FC04-FC08. (PMID:28571163).

16. Ay $P$, Akici A, Harmanc $H$. Drug utilization and potentially inappropriate drug use in elderly residents of a community in Istanbul, Turkey. Int J Clin Pharmacol Ther 2005;43(4):195-202. (PMID:15966466).
17. Pastor Cano J, Aranda García A, Gascón Cánovas JJ, Sánchez Ruiz JF, Rausell Rausell VJ, Tobaruela Soto M. Identifying potentially inappropriate prescriptions in patients over 65 years-old using original Beers criteria and their Spanish adaptation. Aten primaria 2017;49(5):3123. (PMID:28506569).

18. Levy HB, Marcus E-L, Christen C. Adverse reactions/medication safety: beyond the Beers Criteria: a comparative overview of explicit criteria. Ann Pharmacother 2010;44(12):1968-75. (PMID:21081709)

19. Hamilton K, Davis C, Falk J, Singer A, Bugden S. High risk use of OTC NSAIDs and ASA in family medicine: a retrospective chart review. Int J Risk Saf Med 2015;27(4):191-199. (PMID:26756892). 